\title{
THE EFFECT OF PATERNALISTIC LEADERSHIP ON ORGANISATIONAL ETHICAL CLIMATE: THE ROLE OF ORGANISATIONAL JUSTICE AS A MODERATING VARIABLE
}

\author{
Anindya Diah Mentari*)1 and Claudius Budi Santoso*) \\ *) Faculty of Economics and Business, Universitas Gadjah Mada \\ Jln. Sosio Humaniora No.1, Bulaksumur, Yogyakarta, Indonesia 55281
}

\begin{abstract}
This study examines the effect of paternalistic leadership on organisational ethical climate and the role of organisational justice as a moderating variable. The relationship of paternalistic leadership and ethical climate is explained through social learning theory. The respondents used in this study are employees of public organisations as an alternative to the for-profit organisations that previous empirical studies have tended to use. The testing of this model uses the hierarchical regression analysis. The findings of this study confirm the results of earlier studies that paternalistic leadership has a positive and significant impact on organisational ethical climate, particularly in public organisations. The results also show that organisational justice has a moderating role in strengthening the positive influence of paternalistic leadership on organisational ethical climate. The contribution of this study is that, based on contextual factors, effective paternalistic leadership influences the ethical climate in public organisations.
\end{abstract}

Keywords: organisational ethical climate, organisational justice, paternalistic leadership, public organisations

\begin{abstract}
Abstrak: Studi ini menguji pengaruh kepemimpinan paternalistik pada iklim etika organisasi dan peran keadilan organisasi sebagai variabel moderasi. Hubungan kepemimpinan paternalistik dan iklim etika dijelaskan melalui teori pembelajaran sosial. Responden yang digunakan dalam penelitian ini adalah karyawan organisasi publik sebagai alternatif untuk organisasi nirlaba yang cenderung menggunakan studi empiris sebelumnya. Pengujian model ini menggunakan analisis regresi hirarkis. Temuan penelitian ini mengkonfirmasi hasil penelitian sebelumnya bahwa kepemimpinan paternalistik memiliki dampak positif dan signifikan terhadap iklim etika organisasi, khususnya di organisasi publik. Hasil juga menunjukkan bahwa keadilan organisasi memiliki peran moderat dalam memperkuat pengaruh positif kepemimpinan paternalistik pada iklim etika organisasi. Kontribusi penelitian ini adalah bahwa, berdasarkan faktor kontekstual, kepemimpinan paternalistik yang efektif mempengaruhi iklim etika dalam organisasi publik.
\end{abstract}

Kata kunci: iklim etika organisasi, keadilan organisasi, kepemimpinan paternalistik, organisasi publik

\footnotetext{
${ }^{1}$ Corresponding author:

Email: bsantoso@ugm.ac.id
} 


\section{INTRODUCTION}

Various cases of ethical violations by companies and organisations have attracted public attention to issues related to ethical values. Ethical violations can occur in various sectors of organisations (Vardi and Wiener, 1996). These cases potentially reduce public confidence, particularly for those who have a direct link to organisations that commit the violations. Thomas et al. (2004) argue that a violation of ethics, even when it remains within the confines of the law, can damage the image and reputation of an organisation which results in mistrust on the part of customers, and a loss of morale and lower commitment among employees. Organisations that can develop an ethical climate well and consistently will have high ethical standards therefore, will be able to establish longterm relationships or customer loyalty (Johnston and Marshall, 2003 in Mulki et al. 2006).

Victor and Cullen (1988) define organisational ethical climate as the perceptions of a group of individuals regarding matters on morality. This climate determines what constitutes ethical behaviour in the workplace, including what is permitted and forbidden within the organisation. The ethical climate helps employees resolve problems related to ethics, such as answering the question "What should I do?" when faced with a moral dilemma (Homans, 1950 in Cullen et al. 2003). Thus, the organisational ethical climate can be conceptualised as the characteristics of an organisation that constitute the foundations for various decisions, particularly concerning moral issues.

Some previous studies revealed that, there are several antecedents of organisational ethical climate that include social norms, and organisational leadership Dickson et al. (2001); the characteristics of individual members of the organisation as a determinant of ethical climate (Babin et al. 2000; Barnett and Vaicys, 2000). This study seeks to examine the role of leadership style in determining the ethical climate in an organisation. This study bases on that the leader serves as a role model for his or her followers so that they understand the kind of behaviour that is ethically acceptable and understand how ethical issues are handled (Nielsen, 1989). Concerning this, Kidwell and Martin (2005) in Otken and Cenkci (2012) state that when the organisational ethical climate is unclear, employees will look to their leader as an example or as a counsellor in dealing with the ethical dilemmas they are experiencing.
Moreover, leaders set the organisational climate through their authority in exercising control over the normative system of organisations, such as policies, procedures, practices, and reward systems (Barnett and Vaicys, 2000; Burns and Stalker, 1961 in Dickson et al. 2001). Leaders can give explicit instructions about ethics by giving rewards or punishments for certain behaviours (Trevino, 1986).

the antecedents of organisational ethical climate, most of the previous studies attribute the potential to transformational leadership and charismatic leadership (Grojean et al. 2004; Brown et al. 2005; Van Aswegen and Engelbrecht, 2009). However, this study considers there to be a need for a different perspective about acquiring a leader who can affect the ethical climate.

The relevant studies have demonstrated that the concept of paternalistic leadership is relevant to the culture of non-Western countries where leaders have a role in providing care, protection, and guidance to their followers. This paternalistic leadership is found in cultures with high power distance and high levels of collectivism, especially in some Asian countries (Aycan et al. 2000). Several other studies have also noted that the paternalistic leadership style is relatively appropriate to the ethical context (Aycan and Gelfand, 2012; Otken and Cenkci, 2012; Wu and Tsai, 2012; Cheng et al. 2013; Cheng and Wang, 2015). Thus, this study assesses that the paternalistic leadership style comprises specific factors that determine the ethical climate in organisations.

Cheng et al. (2004) define paternalistic leadership as a leadership style that combines discipline and a strong authority with benevolence and moral integrity through leaders who resemble father figures. Paternalistic leadership comprises three dimensions which include authoritarianism, benevolence, and morality. The dimension of morality in paternalistic leader has a very strong connection with the organisational ethical climate. A moral attitude can be broadly described as the behaviour of a leader that is likely to exhibit honourable kindness, discipline, unselfishness, and ethical behaviour as a citizen (Cheng et al. 2004). When a leader can demonstrate moral values consistently, then the moral attitude of that leader will be emulated by his followers. The morality of leaders and their followers can then develop an ethical business climate in their organisations (Neubert et al. 2009). 
Some studies have produced similar findings of the relationship between paternalistic leadership and organisational ethical climate (Erben and Guneser, 2008; Otken and Cenkci, 2012; Cheng et al. 2013). However, inconsistent results on this relationship between paternalistic leadership and organisational ethical climate still found in some other empirical studies (Wu and Tsai, 2012; Cheng and Wang, 2015).

The difference between the results of some research indicates that other factors affect paternalistic leadership in the prediction of organisational ethical climate. This study argues that situational factors influence the direction or strength of the relationship between paternalistic leadership and organisational ethical climate (Otken and Cenkci, 2012). In other words, this study requires a moderating variable as a situational factor in its research, namely organisational justice.

In principle, the concept of organisational justice is the perception of fairness in the regulation of an organisation (Greenberg, 1987; 1990). Employees' perceptions of justice in the organisation seek for evaluations by individuals of whether those who work for that organisation are treated fairly or unfairly. Employees' perceptions of these things can affect their attitudes and behaviours.

Organisational justice has a close connection with organisational ethical climate. Ethical violation is a kind of reaction on the part of employees to perceived injustice within the organisation. This is because employees who are not receiving justice or are being mistreated will be more likely to engage in conduct or behaviour that can be detrimental to their organisation and to other members of the organisation (Masterson et al. 2000).

Most previous studies on the effect of paternalistic leadership on the organisational ethical climate have involved respondents who were employees, the majority of whom worked in for-profit organisations such as manufacturers and service industries (Erben Guneser and 2008; Otken and Cenkci, 2012; Wu and Tsai, 2012; Cheng et al. 2013; Cheng and Wang, 2015). Some of these studies have not paid specific attention in organisations in other sectors such as public organisations.
Several empirical studies have demonstrated that cases of ethical violations have also occurred in public organisations, and have even shown a tendency to be on the increase (Bennett and Robinson, 2000; Lewis and Gunn, 2007; Dick and Rayner, 2013). Concerning this issue, this study feels the need to examine the phenomenon in public organisations. Thus, this study aims to examine the extent to which the influence of paternalistic leadership on organisational ethical climate and the role of organisational justice as a moderating variable apply to public organisations.

\section{METHODS}

The respondents for this research are employees of government organisations, in particular within the province Yogyakarta Special Region. The criterion for respondents is that they have been government employees for a minimum of two years. According to Robinson et al. (1994), an employee is judged to have found a balance in his or her employment relationships after two years of being in a workplace. The respondents will know and understand well the characteristics of their leaders, the organisational ethical climate, and the perceived organisational justice in their organisations. Of the 280 questionnaires distributed, 183 were returned. From those, 179 questionnaires were deemed eligible for processing.

The data required for this study are obtained directly from a set of a questionnaire consisting of closed questions. This questionnaire has two parts, which were: (1) questions on the demographic characteristics of the respondents and (2) questions regarding the three research variables, namely paternalistic leadership, organisational ethical climate, and organisational justice. The questionnaire uses a 5-point Likert scale.

Organisational ethical climate is measured using a questionnaire developed by Victor and Cullen (1988) and revised by Tsai and Huang (2008). The questionnaire consists of 14 statements. The scale has been demonstrated to have acceptable reliability and validity (Schwepker et al. 1997 in Tsai and Huang, 2008). 
Paternalistic leadership (PL) is measured using a Paternalistic Leadership Scale developed by Cheng and his colleagues. This scale is taken from Cheng et al. (2000) in Pellegrini and Scandura (2008). This PL Scale represents three dimensions of leadership, namely paternalistic leadership which encompasses benevolence, along with moral leadership and authoritarian leadership.

Organisational justice is measured using a measurement tool developed by Colquitt (2001). This consists of 20 statements. Some of these items include, "I can express my views and opinions about how procedures are applied in the organisation," "My salary is appropriate for the effort I make for the organisation.," and "My leader treats me with courtesy."

The control variables in this study are age and length of tenure. The respondents' characteristics were measured to ensure the analysis of the impact of paternalistic leadership on organisational ethical climate is not biased.

\section{Development of Hypotheses}

Several researchers state that leadership has a role in creating an ethical climate in an organisation (Neubert et al. 2009; Schminke et al. 2005; Aronson, 2001). When the organisational ethical climate is not clear, employees will see their leader as an example or as a counsellor in dealing with the ethical dilemmas they experience (Kidwell and Martin in 2005 in Otken \& Cenkci, 2012). Also, the association between the leader and the organisational ethical climate also refers to the leader's role as the organisation's normative system controller in matters such as policies, procedures, practices, and reward systems (Barnett and Vaicys, 2000).

The characteristics of paternalistic leadership, in the form of a good personality, being responsible, disciplined, and unselfish, as well as providing an example for subordinates. Moreover, PLare a reflection of the fact that paternalistic leadership is linked to organisational ethical climate. These moral values of the leaders regulate the ethical approach to decisionmaking and can create a moral environment in an organisation (Kanungo and Mendonca, 1996 in Van Aswegen and Engelbrecht, 2009). Thus, leaders will have a significant influence on organisational ethical climate when they better utilize their capacity for moral reasoning to perform morally sound acts (Schminke et al. 2005).

Predictions that paternalistic leadership influence organisational ethical climate is based on social learning theory. This theory, which was developed by Bandura (1971), posits that individual behaviour does not merely arise on its own. Behaviour that appears from within the individual is a reaction resulting from the interaction between the individual's cognitive schema and his or her environment. Individuals will observe the behaviour in the environment as a model, and then it will be imitated and become their behaviour.

Based on some of the considerations above, it is proposed that paternalistic leadership has a positive impact on organisational ethical climate (Otken and Cenkci, 2012). Thus, the first hypothesis of this study is as follows:

H-1: Paternalistic leadership has a positive effect on organisational ethical climate.

Organisational justice often refers to the subjective perception of employees with regard to issues of fairness related to employment and the organisational environment where they work (Moorman, 1991). This perception of fairness within the organisation on the part of employees relates to them knowing whether or not they are treated fairly in the work environment (Henle, 2005). Thus, organisational justice can be defined as employee perceptions of fair and unfair treatment that they receive in the organisation (Folger and Konovsky, 1989).

Several of the previous studies on the theory of justice in organisations have stated that organisational justice can be grouped into three dimensions. These are distributive justice, procedural justice, and interactional justice (Moorman, 1991; Colquitt, 2001; Cropanzano et al. 2007).

Distributivejustice refers to the perception of whether the outcomes that are received by the employee correspond to the efforts, contributions, and achievements that they have contributed and which tend to be compared with what are considered to be relevant parties (Colquitt, 2001). Individuals in an organisation not only evaluate the allocation or distribution of outcomes, they also 
evaluate the process or procedure used in determining that allocation (Thibaut and Walker, 1975 in Colquitt et al. 2001). Justice in the organisation, with regard to the procedures used, is generally known as procedural justice. In addition, the injustice felt by the employees is not only in regard to distribution or procedural issues in a narrow sense, but also pertains to the way in which employees are treated on an individual basis when interaction and meetings taking place (Mikula et al. 1990). The reasonableness of interpersonal treatment experienced by the employee during the application of the organisation's procedures in general is known as interactional justice.

The existence of organisational justice is an indication that a process of social exchange is occurring in an organisation. Social exchange theory explains the reciprocal relationship or transaction between the employee and the organisation (Cropanzano and Mitchell, 2005). With the perspective of social exchange, employees who feel treated fairly by the organisation will feel that the benefits or advantages which they receive are in proportion to the exercise of their obligations to the organisation. This makes the employee in question consider that a balance in the relationship of social exchange has been achieved. Employees who consider that there is a balance in the relationship of social exchange tend to give an excellent performance, such as engaging in positive work behaviour. This is what employees do to reciprocate their fair treatment by their organisation (Shore and Barksdale, 1998).

Under these conditions, the positive impact of paternalistic leadership on developing an organisational ethical climate will be much higher. The behaviour of employees who are dominated by the ethical climate, such as exhibiting sincere intentions in terms of each other's welfare, adhering to policies and procedures, as well as trying to meet the interests of the organisation, are examples of the positive work behaviour of employees who feel treated fairly by the organisation (Gouldner, 1960; Masterson et al. 2000). These circumstances reflect that the more the employees' perceive fairness in their organisation, the more significant and positive impact of paternalistic leadership on developing an organisational ethical climate.

Thus, the fairness perceived by employees is an important variable affecting the organisational ethical climate. The influence of organisational justice on organisational ethical climate indicates that organisational justice can moderate the positive impact of paternalistic leadership on organisational ethical climate. Based on the analysis above, the second hypothesis of this study is as follows:

H-2: Organisational Justice moderates the positive impact of paternalistic leadership on organisational ethical climate.

\section{RESULTS}

The respondents were dominated by a group of employees over the age of 50, (27.9\%). Next was the 31 to 35 age group (16.2\%). Those respondents who had been working for two to five years formed the largest group (21.8\%). These respondents were among those employees who had long work experience meaning they had become familiar with the climate in the organisation, the characteristics of its leader, as well as the administration of justice in the organisation.

The criteria used to determine whether an item is a valid statement are factor loading values. If the statement has a loading factor greater than 0.50 , it is considered valid (Hair et al. 2010). There are 14 items included in the organisational ethical climate factor analysis. The Kaiser-Meyer-Olkin (KMO) value is 0.858 , which is above the acceptable value. These results are characterized by the homogeneous variable structure and the result of 0.000 for the Bartlett Test, which indicates that the variables are in accordance with the provisions of the factor analysis. Factor analysis using varimax rotation is also used for the paternalistic leadership items. There were 26 items of paternalistic leadership that were included in the factor analysis calculation. The KMO value was 0.880 with a homogeneous variable structure and Bartlett Test resul of 0.000. Meanwhile, the KMO value for the 20 items of organisational justice was 0.861 . These results are characterised by the homogeneous variable structure and the result of 0.000 for the Bartlett Test, which indicates that the variables are in accordance with the provisions of the factor analysis.

Reliability analysis was performed on the items pertaining to paternalistic leadership, organisational ethical climate, and organisational justice. From the results of the reliability test on these three categories of items, it was found that the Cronbach Alpha coefficient 
for paternalistic leadership was 0.896 , for organisational ethical climate, it was 0.785 , and for organisational justice it was 0.900 . These three categories of items had excellent reliability, so the measuring instrument used in this study was consistent.

The descriptive statistics in this study serve to clarify the description of the data in the form of average mean values, standard deviation, and the correlation coefficient between variables of paternalistic leadership, organisational ethical climate, and organisational justice. The descriptive statistical values of each of these variables can be seen in Table 1 .

In this study, a multicollinearity test of assumptions was used. There are indications of a problem with multicollinearity when the correlation between the independent variables is high, generally above 0.90 (Hair et al. 2010). The value of the correlation between the independent variables in this study was found to be 0.488. Meanwhile, based on the calculation of the values of tolerance and the variance inflation factor (VIF), the tolerance value for variables showed a value of not less than 0.1 and the VIF was not greater than 10. Thus, the regression model in this study was assessed as not having experienced any problem with multicollinearity and so further analysis could be conducted.

The testing of the model in this study used hierarchical regression analysis. According to Baron and Kenny (1986), testing the hypothesis by using a moderating regression model will be supported if the interaction of independent variables in this case the variable of paternalistic leadership, with the moderating variable being organisational justice if they show significant results. The results of the testing of this research hypothesis can be seen in Table 2 .

This study uses the variables of age and tenure (duration of employment) as control variables. This is done so that the results are not biased by confounding variables. The control variables of age and tenure are not significant or cannot explain the proportion of the variance found in the dependent variables (adjusted R2 $=0.008 ; \mathrm{p}>0.05)$.

Table 1. Average. standard deviation. and correlation coefficient among variables

\begin{tabular}{lccccc}
\hline \multirow{2}{*}{ Variable } & & & \multicolumn{3}{c}{ Correlation } \\
\cline { 5 - 6 } & Mean & Std.Dev & $\begin{array}{c}\text { Paternalistic } \\
\text { Leadership }\end{array}$ & $\begin{array}{c}\text { Organisational } \\
\text { Justice }\end{array}$ & $\begin{array}{c}\text { Organisational } \\
\text { Ethical Climate }\end{array}$ \\
\hline Paternalistic Leadership & 3.21 & 0.64 & 1 & $0.754^{* *}$ & $0.722^{* *}$ \\
Organisational Justice & 3.57 & 0.61 & $0.754 * *$ & 1 & $0.704^{* *}$ \\
Organisational Ethical Climate & 3.58 & 0.53 & $0.722^{* *}$ & $0.704^{* *}$ & 1 \\
\hline
\end{tabular}

** Significant at the 0.01 level (2-tailed)

Table 2. Hypothesis test results

\begin{tabular}{|c|c|c|c|c|}
\hline \multirow{2}{*}{ Step } & \multirow{2}{*}{ Variable } & \multicolumn{3}{|c|}{ Organisational Ethical Climate (OEC) } \\
\hline & & $\mathrm{B}$ & $\mathrm{T}$ & $\mathrm{P}$ \\
\hline \multirow[t]{3}{*}{1} & Age & 0.038 & 0.917 & 0.360 \\
\hline & Tenure & -0.058 & -1.607 & 0.110 \\
\hline & Adjusted $\mathrm{R}^{2}=0.008$ & & & \\
\hline \multirow[t]{2}{*}{2} & Paternalistic Leadership (PL) & 0.603 & 13.535 & 0.000 \\
\hline & Adjusted $\mathrm{R}^{2}=0.513$ & & & \\
\hline \multirow[t]{2}{*}{3} & Organisational Justice (OJ) & 0.611 & 13.070 & 0.000 \\
\hline & Adjusted $\mathrm{R}^{2}=0.495$ & & & \\
\hline \multirow[t]{4}{*}{4} & Paternalistic Leadership (PL) & 0.671 & 4.470 & 0.000 \\
\hline & Organisational Justice (OJ) & 0.543 & 4.743 & 0.000 \\
\hline & PL x OJ & 0.085 & 2.275 & 0.024 \\
\hline & Adjusted $\mathrm{R}^{2}=0.581$ & & & \\
\hline
\end{tabular}


Hypothesis 1 states that paternalistic leadership has a positive effect on organisational ethical climate. Based on the hypothesis test results listed in Table 2, it can be seen that paternalistic leadership has a significant positive effect on organisational ethical climate $(\beta=$ $0.603 ; \mathrm{t}=13.535, \mathrm{p}<0.05)$. The Adjusted $\mathrm{R}$ Square value is found to be 0.513 which indicates that the paternalistic leadership variable affects organisational ethical climate at a level of $51.3 \%$ and for the remaining $48.7 \%$, it is influenced by other variables.

Based on the results of the hypothesis test listed in Table 2, organisational justice significantly moderates the positive effect of paternalistic leadership on organisational ethical climate $(\beta=0.085 ; \mathrm{t}=2.275 ; \mathrm{p}$ $<0.05$ ). The Adjusted R Square value is 0.581 , which indicates that the presence of a moderating variable influences the effect of paternalistic leadership on organisational ethical climate at a level of $58.1 \%$, and for the remaining $41.9 \%$, it is influenced by other variables.

According to the results of the regression analysis, it can be seen that the significance value is 0.000 and the regression coefficient is 0.603 , so the first hypothesis stating paternalistic leadership has a positive effect on the organisational ethical climate is supported fully. Paternalistic leadership is described as the leadership style of someone with authority who assumes that their role is similar to being a parent and they consider this to be their obligation to provide support and protection to others with the attention they give (Aycan et al. 2000). It is demonstrated that the presence of this character of paternalistic leadership encourages subordinates to be more concerned for others, to carry out their activities based on moral beliefs, to adhere to the organisation's policies or other applicable laws, and be willing to help the organisation achieve its objectives. In these circumstances, it can be said that an ethical climate has been created in the organisation.

This is because, basically, the organisational climate is a reflection of the values and cognitive bases adopted by actors who have the power within the organisation (Hambrick and Mason, 1984). In this case, the actor who has power or has a dominant coalition in an organisation is the organisation's leader.

The leader is instrumental in terms of the socialization of behaviours that are acceptable and unacceptable and which will result in fewer unethical decisions in the workplace. If the leader is able to consistently foster moral values, such as behaving reasonably, honestly, and in a caring and reliable way, then the moral attitude of this leader will be emulated by his or her followers (Dickson et al. 2001; Neubert et al. 2009). The morality of the leaders and their followers then develops the ethical work climate within the organisation. Thus, the moral actions of these leaders will arise as the conditions necessary to form an organisation with an ethical climate.

According to the results of the regression analysis, it can be seen that the significance value is 0.024 , and the regression coefficient is 0.085 ; the second hypothesis, which states that organisational justice moderates the positive impact of paternalistic leadership on organisational ethical climate is fully supported. A high level of organisational justice can strengthen the positive influence of behaviours such as benevolence, morality, and authoritarianism shown by a paternalistic leader on the actions of members of the organisation which reflect a climate of care, a climate of independence, a rules climate, a law and order climate, as well as an instrumental climate. In other words, the positive effect will be stronger when the perception of justice received by members of the organisation is better.

The Adjusted R Square value with the presence of the moderating variable is more significant than it is without the moderating variable. Without it, the influence of paternalistic leadership on organisational ethical climate is $51.3 \%$. Meanwhile, with the presence of the moderating variable, the influence is $58.1 \%$. In other words, the effect of paternalistic leadership on organisational ethical climate increases by $6.8 \%$ when moderated by organisational justice. According to these results, it can be said that the organisational justice variable reinforces the positive impact of paternalistic leadership on the organisational ethical climate. Thus, the organisational justice variable can be used to moderate the positive impact of paternalistic leadership on organisational ethical climate.

To be more evident in reporting the results of hypothesis testing in this study, the researchers are presenting two figures to show the effect of two-way interaction that occurs between the variables of paternalistic leadership and organisational justice in terms of organisational ethical climate. 
In explaining the nature of the interaction in this study, the researchers have used the procedure suggested by Aiken and West (1991) in Dawson (2014). This entails calculating the value of organisational ethical climate in different conditions (high and low paternalistic leadership values and high and low organisational justice values). Figure 2 shows that the slope of the regression line for high organisational justice is steeper than the regression line for low organisational justice. This indicates that the positive impact of paternalistic leadership on organisational ethical climate will be stronger when the organisational justice is high.

These research findings are supported by previous studies that investigated the relationship between organisational justice and organisational ethical climate (Deconinck et al. 2012; Fein et al. 2013; Tziner et al. 2015). One of them is by Deconinck et al. (2012) which found that employees will assess their work environment as being more ethical when they believe that they are rewarded fairly for the effort they have given (education and experience) and when they are given the opportunity to express their opinions. The research findings are also assessed in accordance with the theory of social exchange. For example, Peng et al. (2014), show that the social exchange in an organisation will develop when the organisation can take care of the employees so that there are beneficial consequences, such as active workplace behaviour and positive attitudes exhibited by the employees. able to affect an employee's decision as to whether or not to engage in deviant work behaviour (Henle, 2005). Violations of ethics can be a form of reaction against the perceived injustice faced by employees within the organisation. This is because employees who feel that there is no justice or that they are mistreated will be more likely to engage in behaviours that harm the organisation (Masterson et al. 2000).

\section{Managerial Implications}

Furthermore, this result brings practical implication in respect with establishing ethical climate in organizations. First, based on learning social theory, the leader's behaviour has critical roles to produce employees' ethical behaviour. The matter of moral integrity becomes the most important criteria to appointing a leader. Second, the organizational justice also significantly contribute on organizational ethical climate. The leader has to show commitment on executing the established regulation or system, for example is on assessing employees' performance. Employees have trust to the leader as they believe that their leader always base on the established regulation, instead of subjective judgment. In conclusion, the leader's behaviour and the leader's commitment on the fair treatment are subjects to create ethical climate in organizations.

The factor of organisational justice is judged as being

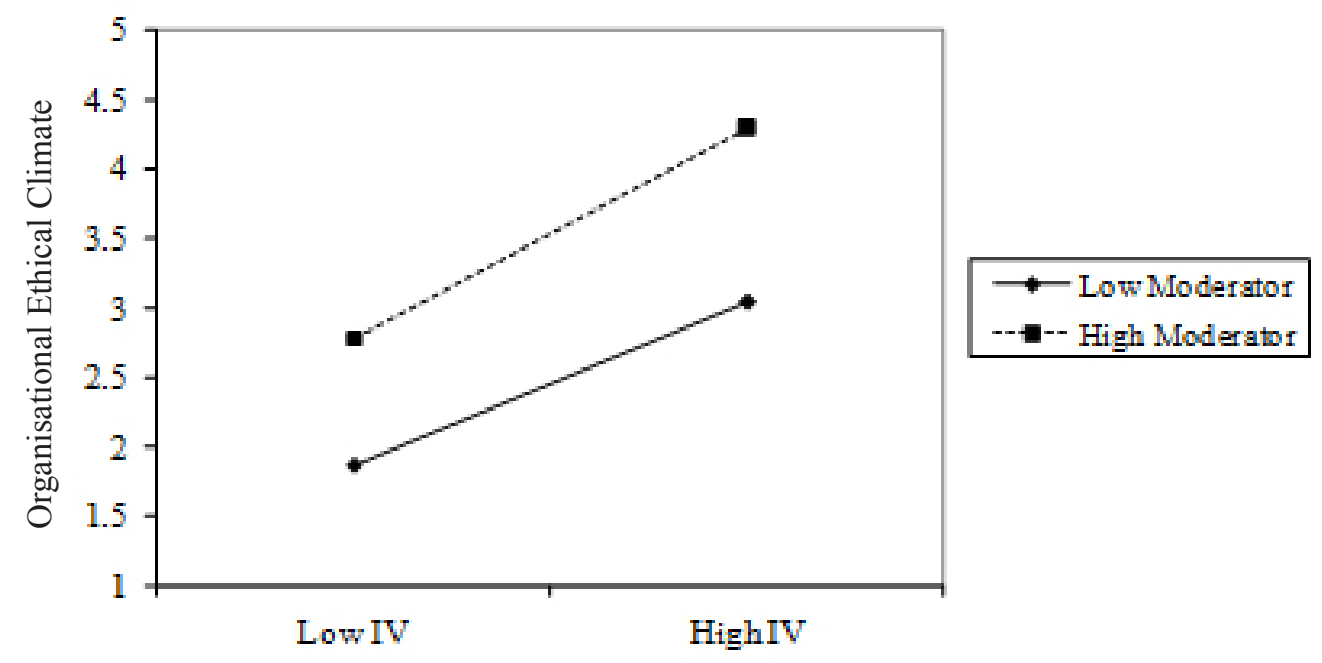

Figure 2.Two-way interaction between paternalistic leadership and organisational justice in terms of organisational ethical climate 


\section{CONCLUSIONS AND RECOMMENDATIONS}

\section{Conclusions}

The test results of this study prove that paternalistic leadership is effective in creating an ethical climate in public organisations. The results of the hypothesis testing are in line with those in several previous studies conducted in for-profit organisations. Thus, the effectiveness of paternalistic leadership in developing an ethical climate is not only valid in for-profit organisations, but also in non-profit organisations. Ultimately, this study provides a contribution on how the concepts of paternalistic leadership, organisational ethical climate, and organisational justice are applied in public organisations. Furthermore, this study has provided findings that are similar to those of empirical studies conducted in the context of for-profit organisations.

Moreover, the results of this study have shown that the factor that strengthens the influence of paternalistic leadership is organisational justice. The positive effect on organisational ethical climate of paternalistic leadership has been proven to be stronger when the perception of the employees regarding the justice that they receive is relatively good.

\section{Recommendations}

In the context of this research, the this study seems that contextual factors, such as cultural factors, play an essential role in strengthening the influence of paternalistic leadership in supporting ethical climate in public organisations. Further research could use this cultural factor as a determinant of leadership style. Besides, this research has focused on the perceptions of individuals. Subsequent research could involve the perception of teams to re-examine the effect of paternalistic leadership on organisational ethical climate.

In addition, the strengthening of the influence of paternalistic leadership on organisational ethical climate will require further testing, for example, by using other moderating variables such as organisational citizenship behaviour. When the level of organisational citizenship behaviour is high, employees will voluntarily contribute more to meeting the interests of the organisation (Katz \& Kahn, 1966 Cheng, Wang, \& Lesmana, 2013). In such situations, employees show their loyalty to their organisations which makes it possible for the leaders to strengthen their influence on creating an ethical climate (Robinson and Marrison, 1995).

\section{REFERENCES}

Aronson E. 2001. Integrating leadership styles and ethical perspectives. Canadian Journal of Administrative Sciences 18: 244-256. https:// doi.org/10.1111/j.1936-4490.2001.tb00260.x.

Aycan Z, Gelfand MJ. 2012. Cross-Cultural organisational psychology. The Oxford Handbook of Organisational Psychology 2. https://doi. org/10.1093/oxfordhb/9780199928286.013.003 3.

Aycan Z, Kanungo RN, Sinha JBP. 2000. Impact of culture on human resource management practices: a 10-country comparison. Applied Psychology: an International Review 49 (1): 192-221. https:// doi.org/10.1111/1464-0597.00010.

Babin BJ, Boles JS, Robin DP. 2000. Representing the perceived ethical work climate among marketing employees. Journal of the Academy of Marketing Science 28(3): 345-358. https:// doi.org/10.1177/0092070300283004.

Bandura A. 1971. Social Learning Theory. Library of congress catalog.

Barnett T, Vaicys C. 2000. The moderating effect of individuals' perceptions of ethical work climate on ethical judgments and behavioural intensions. Journal of Business Ethics 27: 351-362. https:// doi.org/10.1023/A:1006382407821.

Baron RM, Kenny DA. 1986. The moderator-mediator variable distinction in social psychological research: conceptual, strategic, and statistical considerations. Journal of Personality and Social Psychology 51: 1173-1182. https://doi. org/10.1037/0022-3514.51.6.1173.

Bennett RJ, Robinson SL. 2000. Development of a Measure of Workplace Deviance. Journal of Applied Psychology 85 (3): 349-360.https://doi. org/10.1037/0021-9010.85.3.349.

Brown ME, Trevino LK., Harrison DA. 2005. Ethical leadership: A social learning perspective for construct development and testing. Organisational Behaviour and Human Decision Processes 97: 117-134. https://doi.org/10.1016/j. obhdp.2005.03.002.

Cheng B, Huang M, Farh J.2004.Paternalistic leadership and subordinate responses: Establishing a 
leadership model in Chinese organisations. Asian Journal of Social Psychology 7: 89-117. https:// doi.org/10.1111/j.1467-839X.2004.00137.x.

Cheng MY, Wang L. 2015. The mediating effect of ethical climate on the relationship between paternalistic leadership and team identification: a team-level analysis in the Chinese Context. Journal Business Ethics 129: 639-654. https:// doi.org/10.1007/s10551-014-2189-5.

Cheng MY, Wang L, Lesmana SD. 2013. The relationship between patrenalistic leadership and organisational citizenship behaviour-the mediating effect of ethical climate international. Journal of Research in Commerce \& Management 4 (10).

Colquitt, Jason A. 2001. On the dimensionality of organisational justice: A construct validation of a measure. Journal of Applied Psychology 86(3): 386-400. https://doi.org/10.1037/00219010.86.3.386.

Colquitt JA, Colon DA, Ng K, Wesson MJ, Porter OLH. 2001. Justice at the millennium: A metaanalytic review of 25 years of organisational justice research. Journal of applied psychology 86(3): 425-445. https://doi.org/10.1037/00219010.86.3.425.

Cropanzano R, Mitchell MS. 2005. Social Exchange Theory: An Interdisciplinary Review Journal of Management; 31 (874).

Cropanzano R, Bowen DE, Gilliland SW. 2007. The Management of Organisational Justice. Academy of Management Executive 21(4). https://doi. org/10.1177/0149206305279602.

Cullen JB, Parboteeah KP, Victor B. 2003. The effects of ethical climates on organisational commitment: a two-study analysis. Journal of Business Ethics 46(2). https://doi.org/10.1023/ A:1025089819456.

Dawson JF. 2014. Interpreting Interaction Effects. (Online). Diakses 15 Desember 2015, dari http:// www.jeremydawson.co.uk/slopes.htm.

Deconinck J, Johnson J, Busbin J. 2012. The effect of organisational justice on salespersons' perceived ethical climate, organisational commitment and turnover intentions. GSTF Journal on Business Review 2(2).

Dick GPM, Rayner C. 2013. Negative interpersonal behaviour at work: An evidenve based classificationofworkplacebullying. International Journal of Psychology and Behavioural Sciences 3 (4): 95-108.
Dickson MW, Smith BD, Grojean MW, Ehrhart M. 2001. An organisational climate regarding ethics: the outcome of leader values and the practices that reflect them. The Leadership Quarterly 12: 197-217. https://doi.org/10.1016/S10489843(01)00069-8.

Erben GS, Guneser AB. 2008. The relationship between paternalistic leadership and organisational commitment: investigating the role of climate regarding ethics. Journal of Business Ethics 82, 955-968. https://doi.org/10.1007/s10551-0079605-z.

Fein EC, Tziner A, Lusky L, Palachy O. 2013. Relationships between ethical climate, justice perceptions, and LMX. Leadership \& Organisation Development Journal 34(2): 147-163. https://doi. org/10.1108/01437731311321913.

Folger R, Konovsky MA. 1989. Effect of procedural and distributive justice on reactions to pay raise decision. The Academy of Management Journal 32(1):115-130. https://doi.org/10.2307/256422.

Fritzsche, David J. 2000. Ethical climates and the ethical dimension of decision making. Journal of Business Ethics 24: 125-140. https://doi. org/10.1023/A:1006262914562.

Gert B, Culver CM. 1976. Paternalistic Behaviour. Philosophy \& Public Affairs 6 (1): 45-57.

Gouldner AW. 1960. The norm of reciprocity: A preliminary statement. American Sociological Review 25(2): 161-178. https://doi. org/10.2307/2092623.

Greenberg J. 1987. A taxonomy of organisational justice theories. The academy of management review. 12 (1), 9 -22.

Greenberg J. 1990. Employee theft as a reaction to underpayment inequity: the hidden cost of pay cuts. Journal of Applied Psychology 75 (5): 561568.

Grojean MW, Resick CJ, Dickson MW, Smith DB. 2004. Leaders, values, and organisational climate: Examining leadership strategies for establishing an organisational climate regarding ethics. Journal of Business Ethics 55: 223-241. https://doi.org/10.1007/s10551-004-1275-5.

Hair et al. 2010. Multivariate Data Analysis. 7th edition. New Jersey: Pearson Education.

Hambrick DC, Mason P. 1984. Upper echelons: The organisation as a reflection of its top managers. Academy of Management Review 9: 193-206. https://doi.org/10.5465/amr.1984.4277628. 
Henle CA. 2005. Predicting workplace deviance from the interaction between organisational justice and personality. Journal of Managerial Issues, 17 (2): 247-263.

Lau VCS, Au WT, Ho JMC. 2003. A qualitative and quantitative review of antecedents of counterproductive behaviour in organisations. Journal of Business and Psychology 18 (1): 7399. https://doi.org/10.1023/A:1025035004930.

Lewis D, Gunn R. 2007. Workplace bullying in the public sector: Understanding the racial dimension. Public Administration 85(3): 641-665.https:// doi.org/10.1111/j.1467-9299.2007.00665.x.

Martin KD, Cullen JB. 2006. Continuities and extensions of ethical climate theory: a metaanalytic review. Journal of Business Ethics 69(2):175-194. https://doi.org/10.1007/s10551006-9084-7.

Masterson SS, Lewis K, Goldman BM, Taylor MS. 2000. Integrating justice and social exchange: the differing effects of fair procedures and treatment on work relationships. Academy of Management Journal 43(4): 738-748. https:// doi.org/10.2307/1556364.

Mikula G, Petrik B, Tanzer N. 1990. What people regard as unjust: Types and structures of everyday experiences of injustice. European Journal of Social Psychology 20: 133-149. https://doi. org/10.1002/ejsp.2420200205.

Moorman RH. 1991. Relationship between organisational justice and organisational citizenship behaviours: do fairness perceptions influence employee citizenship? Journal of Applied Psychology 76(6): 845-855. https://doi. org/10.1037/0021-9010.76.6.845.

Mulki JP, Fernando J, William BL. 2006. Effects of ethical climate and supervisory trust on salesperson's job attitudes and intentions to quit. Journal of Personal Selling \& Sales Management 26 (1): 19-26. https://doi.org/10.2753/PSS08853134260102 .

Neubert MJ, Carlson DS. Kacmar KM, Roberts JA, Chonko LB. 2009. The virtuous influence of ethical leadership behaviour: evidence from the field. Journal of Business Ethics 90: 157-170. https://doi.org/10.1007/s10551-009-0037-9.

Nielsen RP. 1989. Changing unethical organisational behaviour. Academy of Management Executive 3: 123. https://doi.org/10.5465/ame.1989.4274762.

Otken AB, Cenkci T. 2012. The impact of paternalistic leadership on ethical climate: the moderating role of trust in leader. Journal of Business Ethics 108: 525-536. https://doi.org/10.1007/s10551011-1108-2.

Pellegrini EK, Scandura TA. 2008. Paternalistic leadership: A review and agenda for future research. Journal of Management 34(3): 566593.https://doi.org/10.1007/s10551-011-1108-2.

Peng AC, Schaubroeck JM, Li Y. 2014. Social exchange impications of own and coworkers' experiences of supervisory abuse. Academy of Management Journal 57 (5): 1385-1405. https:// doi.org/10.5465/amj.2012.0080.

Robinson SL, Kraatz M S, Rousseau DM. 1994. Changing obligations and the psychological contract: a longitudinal study. Academy of Management Journal 37(1): 137-152. https:// doi.org/10.2307/256773.

Robinson SL, Morrison EW. 1995. Psychological contracts and OCB: the effect of unfulfilled obligations on civic virtue behaviour. Journal of Organisational Behaviour 16: 289-298.https:// doi.org/10.1002/job.4030160309.

Rohrmann CA, Rego C. 2014. Private law and state paternalism: too much legal regulation of private life? Journal of International Commercial Law and Technology 9 (4).

Schminke M, Ambrose ML, Neubaum DO. 2005. The effect of leader moral development on ethical climate and employee attitudes. Organisational Behaviour and Human Decision Processes, 97: 135-151. https://doi.org/10.1016/j. obhdp.2005.03.006.

Schwepker CH, Good DJ. 2009. Ethical Climate's influence on sales management practices. Journal of Selling \& Major Account Management 9 (1).

Shore LM, Barksdale K. 1998. Examining degree of balance and level of obligation in the employment relationship: A social exchange approach. Journal of Organisational Behaviour 19: 731.

Thomas T, Schermerhorn JR, Dienhart JW. 2004. Strategic leadership of ethical behaviour in business. Academy of Management Executive 18(2). https://doi.org/10.5465/ ame.2004.13837425.

Trevino LK. 1986. Ethical decision making in organisations: a person $\mathrm{x}$ situasion interactionist model. Academy of Management Review 11: 601617. https://doi.org/10.5465/amr.1986.4306235.

Tsai MT, Huang CC. 2008. The relationship among ethical climate types, facets of job satisfaction, and the three components of organisational 
commitment: a study of nurses in Taiwan. Journal of Business Ethics 80(3): 565-581. https://doi.org/10.1007/s10551-007-9455-8.

Tziner A, Felea M, Vasiliu C. 2015. Relating ethical climate, organisational justice perceptions, and leader-member exchange (LMX) in Romanian organisations. Journal of Work and Organisational Psychology 31: 51-57.

Van AAS, Engelbrecht AS. 2009. The relationship between transformational leadership, integrity and an ethical climate in organisations. South African Journal of Human Resource Management 7(1):221-229. https://doi.org/10.4102/sajhrm. v7i1.175.

Vardi Y, Wiener Y. 1996. Misbehaviour in organisation: A motivational framework. Organisation Science 7(2): 151-165. https://doi.org/10.1287/ orsc.7.2.151.

Victor B, Cullen JB. 1988. The organisational bases of ethical work climates. Administrative Science Quarterly 33(1): 101-125. https://doi. org/10.2307/2392857.

Wu YC, Tsai PJ. 2012. Multi dimensional relationships between paternalistic leadership and perceptions of organisational ethical climates. Psychological Reports: Human Resources \& Marketing 111 (2): 509-527. https://doi.org/10.2466/01.17. PR0.111.5.509-527.

Wyld DC, Jones, Coy A. 1997. The importance of context: the ethical work climate construct and models of ethical decision making: an agenda for research. Journal of Business Ethics 16 (4): 465-472. 